\title{
一側迷路破壞性眼球震燙二對スル 緊張性眼反射ノ影響
}

佐 田 澹 洋

[京都帝國大學醫學部耳鼻咽喉科教室(主任星野教授)]
1. 序 言
2. 實驗方法
3 , 成績前 $=$ 其觀察
4. 䊅 論

\section{1. 序言}

耳迷路ノ回轉又心温熱刺载二因テ發來スル眼球震偪ガ，頭位 $\ni$ 空間二於 テ變ズル時, 該頭位ニ相當セル，換言スレバ各牛規管ノ各位相ニ一致セル 一定ノ變化 7 來ス ，已二早ク Bărăny, ${ }^{(1)} K^{\prime}$ ubo, ${ }^{(2)}$ De Kleyn u. Magnus, ${ }^{(3)}$ Van der Hoeve ${ }^{(4)}$ Hofer ${ }^{(10)}$ 等二依テ詳細二觀察スラル、處ナリ. (我國二於 テハ, 星野. ${ }^{(5)}$ 飯田. ${ }^{(6)}$ 影山・ ${ }^{(7)}$ 富岡. ${ }^{(8)}$ 等アリ) 而シテ其變化ノ由來八, 主トシテ回轉又 温熱刺载二因テ誘致スル內淋巴液ノ流動 シシテ輕易ナラ

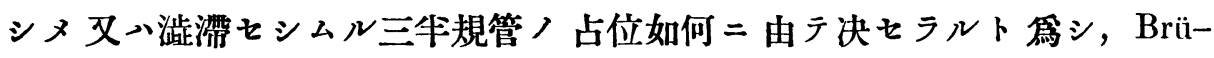
nings ${ }^{(9)}$ 八之 7 各牛规管，刺戟適位又ハ不適位ト名ヅケタリ，師于回轉刺 戟ニ對シテハ頭位ノ變化二依テ水本位ニ置カレタル牛規管ガ最モ適位ニシ テ, 鉛㨁位二近キ占位ノ牛規管ナルニ從七不適位ニアリ・温熱刺戟二對シテ 八之ト全ク反對二, 鉛直位牛規管最適位二, 水本位牛規管最不適位ナリ・以 上ノ解說タルャ頗ル簡明ニシテ吾人 $シ$ シ容易二其依テ然ル所以ヨ理解セ シム・然ルニ一方動物頭位 $コ$ 單二空間二於テ變ズル時ハ，前庭性緊張性眼 球反射ナル一種ノ眼球變化 $\exists$ 招致シ, 該變化ハ一定ノ頭位ニ於テ一定シ，且 ツ頭位持續ノ間其位置 $ヨ$ 保持スルハ人ノ知ル所ナリ．即チ前記頭位二於ケ ル回轉又心温熱性眼球震盪二際シテハ同時二又緊張性眼球移動ガ大ナル影 響ヨ與フベキヨ考慮セザルベカラズ. 師チ各種頭位二俄テ影響セラル、眼 球震盪ノ戀化》單二淋巴流動ノ難易ノミヨ以テ解明スルハ未ダ必ズシモ全 シト言ヒ難ク，此際一部緊張性眼反射ノ影響习加减考察スルタ要ス。從爽 各種眼球震盪ノ頭位ニ依ル變化ヨ觀察セルモノ多キニ拘ラズ末ダ其影響ノ 
程度 $ヨ$ 純粹二數字二俄テ實證セルモノナシ・即チ著者ハ茲二淋巴ノ流動二 關係ナキ一側迷路破壞性眼球震盪二對シ，緊張性眼反射ガ果シテ幾何程度 ノ影響ヨ演ズベキャヨ, 既報哏球震盪ノ力學的観察二於テ述べタル，所謂 極限荷重 ${ }^{(14)}$ (眼球震盪時眼筋ノ攣縮ガ荷重二依テ最早收縮シ能ハザルニ至 リシ時ノ最大重量）ノ計測ヨ利用シテ観察セリ。

\section{2. 實 驗 方 法}

實驗動物ハ家鬼ニシテ，迷路破壞法ハ從來己二多クノ報告アルラ以テ省 略ス (主トシテ星野敎室二於ケルモノ二依ル) ${ }^{(5)(11)(12)}$ 卿筋分離, 眼球剔出, 荷重計測等ノ諸操作モ亦著者ノ眼球震蕰ノ力學的觀察第2. 第3. 報二述ぺタ ルト同一ナルョ以テ略シ，只頭位い本實験二最モ重要ナルョ以テ茲二再錄 ス.

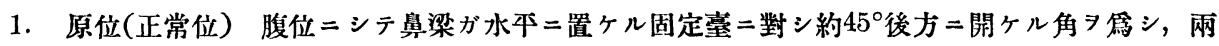
眼へ左右同高ニシテ,軀幹入頭部卜正值二保持シテ頸反射/影響 $コ$ 絕對二避ケシメ タ儿體位

2. 第一頭位. 原位 $\exists$ リ矢狀面內 $=$ 於テ鼻孔 $\exists$ 上方 $=90^{\circ}$ 回轉シ, 頭八上部 $=$ 尾端八下位 $=$ 在儿鉛 直體位

3 第二頭位. 原位 $\exists$ ソ矢狀面內 $=$ 於テ鼻孔 $7 下=90^{\circ}$ 回轉シ, 頭部八下方二尾端八上位 $=$ 在ラシ ×タル鉛直體位.

4. 第三頭位 右耳 7 前額面內二於テ原位 $コ$ 右侧 $=90^{\circ}$ 回轉シテ眞直二下位ニ來ラシメタル侧位 ニシテ, 從テ左耳八右耳, 值上=在り.

5 第四頭位. 左耳 7 前額面內二於テ原位 $\exists$ リ左方 $=90^{\circ}$ 回轉シテ䢐直 $=$ 下位 $=$ 來ラシメタル側位 ニシテ從テ右耳八左耳/直上二在り.

而シシ本實驗二於テ最モ混合シ易キ緊張性頸性眼反射 7 嚴格二遮斷スべ ク特ニ注意 $ヨ$ 拂へルハ勿論トス。

猊緊張性鉛值移動 兩眼 $\ni$ 側立性二所有セル家鬼二於テハ左右常二非對 程性ニシテ著シク上下㨁筋ノ觀察ヨ複雜ナラシムル 以テ著者い全例左側 迷路破壞ヨ行七檢查根ハ術側ノミヨ探レリ。

\section{3. 成精前二其觀察}

但シ動物ハ總テ左側迷路破壞セルモノニシテ、檢査眼筋ハ術側ナリ重量單位ハ瓦トス。

上揭各頭位二於ヶル，六眼筋ノ極限荷重ノ和(第一表右端) $ヨ$ 觀 $ル$, 第 


\begin{tabular}{|c|c|c|c|c|c|c|c|c|}
\hline 動物番號 & 頭位 & 上斜筋 & 下斜筋 & 内直筋 & 外值筋 & 上直筋 & 下直筋 & 合 計 \\
\hline \multirow{5}{*}{ Nr. 1.} & 原 位 & 10.0 & 4.0 & 9.0 & 24.0 & 5.5 & 24.5 & 77.0 \\
\hline & 第一頭位 & 12.5 & 1.0 & 8.0 & 22.5 & 3.5 & 22.5 & 70.0 \\
\hline & 第二頭位 & 4.5 & 11.0 & 8.5 & 23.0 & 6.0 & 27.0 & 80.0 \\
\hline & 第三頭位 & 2.5 & 4.0 & 4.0 & 22.5 & 4.5 & 11.5 & 50.0 \\
\hline & 第四頭位 & 13.5 & 4.5 & 10.5 & - 25.5 & 12.0 & 25.5 & 92.5 \\
\hline \multirow{5}{*}{ Nr. 2.} & 原 位 & 8.0 & 5.0 & 10.0 & 30.0 & 7.5 & 20.5 & 81.0 \\
\hline & 第一頭位 & 11.0 & 2.0 & 10.5 & 29.0 & 8.0 & 20.0 & 80.5 \\
\hline & 第二頭位 & 5.5 & 11.5 & 8.5 & 32.0 & 10.5 & 18.0 & 86.0 \\
\hline & 第三頭位 & 0 & 0 & 0 & 7.0 & 3.5 & 7.5 & 18.5 \\
\hline & 第四頭位 & 10.5 & 7.5 & 15.0 & 33.5 & 12.5 & 24.0 & 103.0 \\
\hline \multirow{5}{*}{ Nr. 3.} & 原 位 & 12.5 & 2.0 & 9.5 & 25.0 & 7.0 & 20.0 & 76.3 \\
\hline & 第一頭位 & 14.0 & 0 & 8.5 & 23.5 & 5.5 & 18.5 & 70.0 \\
\hline & 第二頭位 & 5.0 & 3.5 & 6.0 & 22.0 & 4.0 & 23.0 & 63.5 \\
\hline & 第三頭位 & 0.5 & 0 & 1.0 & 4.5 & 0 & 1.0 & 7.0 \\
\hline & 第四頭位 & 15.5 & 3.0 & 14.5 & 26.5 & 8.0 & 24.5 & 92.0 \\
\hline \multirow{5}{*}{ Nr. 4.} & 原 位。 & 9.5 & 11.5 & 17.5 & 31.5 & 12.5 & 29.5 & 112.0 \\
\hline & 第一頭位 & 12.0 & 2.0 & 15.0 & 27.5 & 7.0 & 25.5 & 89.0 \\
\hline & 第二頭位 & 3.5 & 12.5 & 15.0 & 28.0 & 10.0 & 25.0 & 94.0 \\
\hline & 第三頭位 & 1.5 & 3.5 & 4.0 & 5.0 & 4.5 & 11.0 & 29.5 \\
\hline & 第四頭位 & 10.5 & 10.5 & 16.5 & 32.5 & 13.0 & 28.0 & 111.0 \\
\hline \multirow{5}{*}{ Nr. 5.} & 原 位 & 15.0 & 16.0 & 12.0 & 25.0 & 6.0 & 150 & 89.0 \\
\hline & 第一頭位 & 18.5 & 5.0 & 10.5 & 24.0 & 3.0 & 13.0 & 74.0 \\
\hline & 第二頭位 & 7.5 & 17.0 & 10.0 & 20.5 & 8.0 & 14.0 & 77.0 \\
\hline & 第三頭位 & 0 & 2.0 & 3.0 & 18.0 & 3.5 & 5.5 & 32.0 \\
\hline & 第四頭位 & 14.0 & 15.5 & 14.5 & 28.5 & 14.5 & 18.0 & 105.0 \\
\hline
\end{tabular}

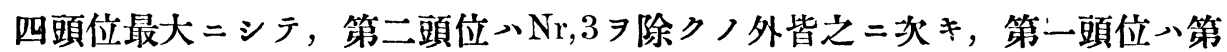
三位ニアリテ，第三頭位最小ナリ。之レア原位ト比較スレパ，第四頭位へ 


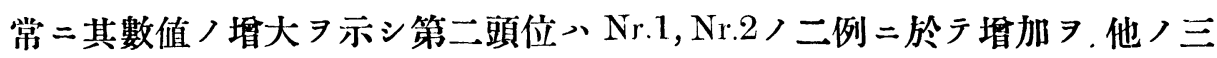
例 $=$ 於テ减少 $ᄏ$ 示ス. 第一乃至第三䫓位ハ常二原位ノ際ヨリモ减少 殊二第三頭位、其度著明ナリ。

一側迷路破壞性眼球震盍ガ迷路術側 ア活潑ナラシメ, 術側 從來已二認メラル、所ニシテ，是二依テ側頭位二於ヶル眼球震盪八常二上 位二置カレタル迷路二依ラ發現七ラレ，下位ニアル迷路ハ之二關與セザル カ或ハ關與スル事アルモ其度極メテ微弱ナルモノト七ラル。此理由二化テ 觀ルニ，上揭成績二於ヶル第四頭位ノ極限荷重ガ，原位ノ夫レョリ著シク 大二，第三頭位ノ際ハ著シクホナル數值ヨ示セルハ單純ナル緊張性眼反射 ノ影響卜篇スベカラザル事, 元ョリ論 俟タザルモ, 各眼筋個々二就テ其 極限荷重ノ增减 $\ni$ 觀察スレバ，或程度ノ緊張性反射ノ影響 $\ni$ 窥七得ハガ如 シ.

隻ンデ各眼筋個々ニ於ケル極限荷重㙕减ノ狀態习考察セン篇メ，上揭五 例各筋ノ同一頭位二於ヶル數值 率ノ增减指數习表示スレバ次ノ如シ。

\begin{tabular}{|r|r|r|r|r|r|r|}
\multicolumn{2}{c}{ 第 } \\
\hline 頙位 & 上斜筋 & 下斜筋 & 内直筋 & 外直筋 & 上直筋 & 下㨁筋 \\
\hline 原 位 & 100 & 100 & 100 & 100 & 100 & 100 \\
第一頭位 & +24 & -75 & -9 & -7 & -30 & -9 \\
第二頭位 & -53 & +46 & -17 & -8 & \pm 0 & -2 \\
第三頭位 & -92 & -75 & -79 & -58 & -58 & -67 \\
第四頭位 & +16 & +8 & +22 & +8 & +60 & +10 \\
\hline
\end{tabular}

第一頭位

本頭位二於テハ上斜筋獨り增加指數 ヨ示シ, 他ノ五筋ハ减少シ, 殊二下 斜筋二於テ特二著明ナリ。郎于頭部 $习$ 鉛直上位 $(90)^{\circ}=$ 置キタル際ノ眼球 震蕰、一般二减弱七ラルレドモ獨り上斜筋ノ緊張性反射ノ影響习受ケラ眼 球震嚍ノ方向ガ主トシテ眼球危膜上橡 ヨ前方二向ハシムル處ノ車軸回轉性 運動ヨ强度ニ加味セラルベキヨ想像セシム。 


\section{第二頭位}

下斜筋獨り坦加指數 减少シ, 殊二上斜筋二於テ特二减少度,著明ナル事, 第一頭位ノ際ト全ク 反對ノ狀况ニアリ，師チ頭位 $ヨ$ 鉛直二 $90^{\circ}$ 下位二置ケバ，其際ノ眼球震盪 ノ方向い主トシテ下斜筋ノ緊張性反射ノ影響ヨ受ヶテ角膜椽上極ヨ後方二 向ハシムル處ノ車軸回轉性運動 ヨ著シ・ク加味セラルベキヨ觀ル。

\section{第三頭位}

本頭位ニテও，已述ノ如ク，一側迷路曠置側

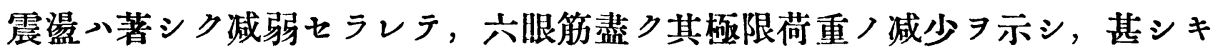
一第一表 Nr 2 ノ上下斜筋及內㨁筋， $\mathrm{N}_{1} 3$ ノ下斜筋及上直筋，Nr.5 ノ上斜筋

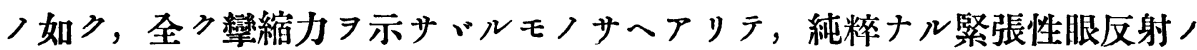
影響ヨ窺フ事困難ナリ・只强テ之ヨ求ムレバ，鉛值運動筋二於テ其减少度 ガ, 他ノ水本及回旋運動筋二比シ, 稍少ナキ 影響ヨ鉛直運動ニ及ボセルョ思ハシムルノミ・

第四頭位

第三頭位ト全ク区對二，一側迷路軸置側 $7 下$ 位二置キタル篇メ，眼球震 盪ガ著シク增强セラレテ六眼筋啸增加指數ヨ示シ，殊二上直筋二於テ隔 絶シラ其增加ノ最大ヨ示セルハ，頭位 （本實驗ニテハ下位ニアリ）ガ緊張性反射ノ影響二依テ鉛直運動 ナラシメタルョ知ルニ足ル。

焰以上ノ觀察 綜覧スレバ緊張性眼反射ガ一側迷路破壊性眼球震盪二對 スル影響い，一般二上・下斜筋二特二明膫二，上.下直筋二於テ可ナリ著 明ニ現、ル、外何レノ頭位タルョ問ハズ，六眼筋二於テ皆多少ノ影響ヨ被 リ，前庭性緊張性眼反射ガ內外直筋二存在セザルハ今日最早殆ド確定事ナ ルモ，少クトモ著者ノ上記實驗二於テハ，各半規管 通管腔ヨ絕對二遮断セラレザル限り。内外直筋二對シテモ亦多少ノ他ノ四 筋二於ヶル緊張性眼反射ノ影響习波及スルヨ認知七シムルモノナリ.

而シテ又緊張性眼反射》淋巴流動ノ如何(適位・不適位)二拘ラズ該緊張 㙕加筋二屬えル眼球運動

\section{4. 結 、論}


1）一側迷路破壞性眼球震盪二於ケル眼筋ノ極限荷重ハ，其頭位 於テ筑スル時一定ノ增减 ノ極限荷重ハ常二增大七ラレ, 此際拮抗筋ノ夫レハ减少ス。

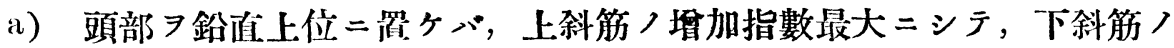
减少指數亦最大ナリ。

b) 頭部 $\ni$ 鉛㨁下位二置ケバ，下斜筋ノ增加指數最大ニシテ，上斜筋ノ 减少指數亦最大ナリ。

c) 頭部 $习$ 迷路曂置側 7 上側位 $\left(90^{\circ}\right)$ 二置ク時ハ，全眼筋著シク其極 限荷重ノ减少 $ᄏ$ 示スモ，其中特二上下值筋 $=$ 於テ其减少指數ノ小 示ス。

d) 頭部 迷路曠置側 $7 下=$ 側位 $\left(90^{\circ}\right)$ 二置ケバ，全眼筋著シク極限荷 重ノ增大 $习$ 致シ，上㨁箭二於テ特二其最大增加指數 7 示ス.

2）緊張性眼反射い內外陮箭二存在セザルヨ定說トスレドモ，半規管各個 ヨ嚴密二隔絕シテ其管腔ノ連絡ヨ遮斷セラレザル限リ。該箭ノ眼球震璗 性收縮力二對シ, 各頭位共ニ多少ノ影響 $コ$ 與フ・

3）上記特發性腿球震盪二對スル緊張性前庭性眼反射ノ影響ヨ綜覧スレバ 該影響ハ內淋巴流動ノ適位・不適位ニ關係ナクシテ，著明ニ現ハル、ヨ 知ル.

\section{Literatur.}

1) Bărăny; Physiologie u. Pathologic des Bogengangapparates beim Menschen. Leipzig u. Wien. 1907. $\quad 2)$ I. Kubo; Über die von N. acusticus ausgelösten Augenbewegungen. Arch. f. d. gesammt. physiologie $1906 . \quad 3)$ De Kleyn u. Magnus; Tonische I abyrinthreflex auf die Augenmuskeln. Pfluger's Archiv. 1920.

4) Van der Hoeve

u. De Kleyn; Tonische Labyrinthreflex anf die Augen. Pfligger's Archiv. 1017.

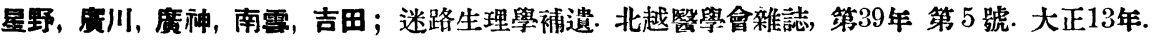
6）饭田；大日本耳鼻咽喉科學會々報 第 26 卷，第3號 大正 9 年. 大日本耳悬咽喉科學會々報 第27卷, 年3 號 大正10年.

臨床. 第15卷, 大正 12 年 3 月.

7）景山；溫熟性眼球震燙／實驗的研究.耳鼻咽喉科京都

8）富周；片側迷路破壞海䧆二於ケル廻轉後眼球震

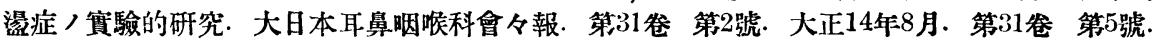
大正15年2月.

9) Brünings; Zeitschr. f. Ohr. Bd. 63, 1911.

10) Hofer ; Zeitschr. f. Ohr. Bd. 9. 1911.

11）展神；迷路性筋緊張／實驗的研究. 耳鼻咽喉科 臨床, 第20卷第3號. 12) Yoschida u. Saito; Eine neue Methode zur Ausschaltung u. der calorischen Reizung des Labyrinths beim Kaninchen. The Otorhino-and Leryngological clinic. Vol No. IV. 1927. 13) R. Barany; Jauernde Veränderung des spontanen Nystagmus bei Veranderung der Kopflage. Monatschr. f. Ohr. Jahrg. 47. 1913.

佐田；前庭性眼球震燙，力學的觀察. 第一. 第二. 第三弨. 耳鼻咽喉科臨床. 本號所載 


\title{
On the influence of vestibular tonic reflex on Nystagmus of eye caused by exstirpation of a labyrinth of one side.
}

\author{
$\mathrm{BY}$ \\ T. SADA. \\ From the Oto-Rhino-Laryngological Clinic of Kioto Imperial University \\ (Director: Prof. T. Hosmino.)
}

The author observed, by measuring the limiting load of eye muscle in case of Nystagmus which he formerly reported, the influence of vestibular tonic reflex of eye on Nystagmus caused by breaking of a labyrinth of one side and he obtained the following facts:

1) The liniting load, of an eye muscle in case of Nystagmus caused by breaking of one labyrinth being broken, shos a definite increase as well as decrease by changing the position of its head in space and a limiting load of an eye muscle, which Tonus increases reflectively and tonically always, increases; in this case that of the antagonist decreases.

a) When the head is posed vertically upward at $90^{\circ}$ both the positive index of M. obliq. sup. and negative index of M. obliq. inf. are the greatest; other four muscles show a slight negative index.

b) When the head is posed downward vertically at $90^{\circ} \mathrm{M}$. obliq. inf. shows the greatest positive index and M. obliq. sup. the greatest negative index, and the rest four muscles show a s'ight negative index.

c) When the head is posed to one side at $90^{\circ}$, the labyrinth of its upper side being broken, all eye muscles decrease remarkably their limiting load, especially M. rect. sup. and inf. show their negätive index decreased.

d) When the head is posed to one side at $90^{\circ}$, the labyrynth of its under side being broken all eye muscles show remarkable increase of their limiting loads, especially M. rect. sup. shows the greatest positive index.

2) It is generally believed that the vestibular tonic reflex of eye does not exists in M. rect. int. and ext. but in his experiments the auther recognised that these muscles also feel a slight influence on each pose of head above mentioned.

3) To sum up the influence of vestibular tonic reflex of eye on the above mentioned spontaneous eye-nystagmus, that influence appears quite clearly without any concern to the adequate position of aflow of the Endolymph. 